\title{
Pandemic Parenting: A Biopsychosocial Framework
}

\author{
Joseph D Sclafani* \\ Professor of Psychology, The University of Tampa, USA
}

Submission: October 29, 2020; Published: November 17, 2020

*Corresponding author: Joseph D Sclafani, PhD, Professor of Psychology, Emeritus, The University of Tampa Tampa, FL, USA

\begin{abstract}
During the current COVID-19 pandemic, many parents are struggling with how to adjust their parenting so

that their children maximize their positive growth and have the least harm or damage. As an author of parenting books, I suggest a biopsychosocial framework for parents to organize their thinking and planning.

This opinion piece offers guidance for parents or those who work with parents of dependent children. Biopsychosocial approaches embrace all global developmental aspects that impact children. A biopsychosocial context refers to the interaction, often reciprocal, between biological and maturational roots, psychological phenomena, and social factors. Social factors play a big role and refer to relationships with and in your family, with peers, and others in the world.
\end{abstract}

Keywords: Pandemic parenting; Biopsychosocial

\section{Biological and Health Issues}

During the current pandemic, physical safety has become a priority concern for parents. This begins with keeping children safe by engaging in protective behaviors. Parents must model and reinforce proper and appropriate safe behaviors. Parents are encouraged to teach their children about social distancing, mask wearing, general hygiene and hand washing, and minimizing time spent in enclosed spaces. The latter issue also extends to decisions about sending children to school or engaging in distance learning or home schooling.

Limiting time with others outside of their family unit also plays into the physical domain as it interacts with the social domain. Some families have created "pods" which are small groups of people known to be socially distant from others and free of the virus. Some of these pods are for limited play groups and others extend to a small circle of extended family and friends. Others have created learning pods which simulate in-class school environments. These pods are important in that they help safeguard the physical safety and health of the child, but also allow for some interpersonal interactions and important opportunities for social development.
Also related to enforcing health and safety is the importance of proper medical and dental care. Children still need to follow their vaccination schedules and to have their annual physical exams and dental visits. There is concern that many children have missed their vaccinations for fear of exposure to the virus by parents. Dental offices and procedures have been modified to be COVID-safe. Parents must be assured that there are safe protocols in place to allow these necessary medical and dental interventions. And then parents must be sure their children get these services.

Finally, there is concern that children are not getting enough exercise or appropriate levels of physical activity. Consequences of these activity deficits include weight gain and obesity, and other diet-related deficiencies. And again, this plays into social development worries as children miss chances to interact with peers and learn age appropriate pro-social and altruistic behaviors such as sharing and cooperative ventures. Some game playing and other peer interactions can be done virtually and video games are popular. But these have different outcomes than peer-to-peer inperson activity. 


\section{Pandemic Parenting}

Related to physical activity levels is their role in stress reduction and anxiety management. Physical activity is a healthy way to reduce and manage stress levels. Children need to be able to run, jump, climb and engage in rigorous physical activity. These activities assist in physical development, improvements in strength levels and coordination/athleticism, and assist in general healthy growth. Anxiety levels in children may also be addressed with physical activity as a way to help reduce feelings of anxiety and worry. Such activity can also serve as a distraction for obsessing or ruminative behaviors. Physical outlets for anxiety reduction are a healthy alternative to overeating or substance abuse experimentation. Parents must be creative and find ways to allow their child(en) to get these physical outlets.

\section{Psychological Issues}

In the realm of psychological issues, we include overall cognitive development, language development and literacy, and intellectual growth. The single best thing a parent can do to facilitate language is to speak with and to their child as much as possible. Quantity of conversation is important. But so is quality. While spending more time together at home because of distancing, this can be a positive outcome of pandemic parenting.

Almost as important as conversation is the act of reading to a younger child. Ideally, your child is exposed to new words AND gets to ask questions about those words or elements of a story. For a parent, reading is not as good as reading plus asking your child questions about what is being read. For older early elementary children, a good parental vocabulary will stimulate language. Encouraging your child to read on his/her own is also important. If you can teach your child to love reading, they will be on a lifelong learning experience. Modeling reading is also wise; if your child or teen sees you reading (books, e-books, Kindles), they see the activity as important and want to copy you. Teens who are good readers will find college easier. As for other cognitive skills, you as a parent can provide access to the interesting stuff your child will want to pursue. As a parent, here is where you interact with your child's schooling. If you choose home schooling, your parenting is not as impacted as you were already working at home. If you are doing distance learning, you can interact with the materials your child is working on. Where possible, good parenting will involve working on developing creativity in your child. Creative tasks that involve and develop spatial ability are coloring and painting, molding/ sculpting with clay, and photography. These activities will allow your child to see how to use shapes, space, organization and the way things can be connected. You can do virtual tours of museums and show your children masterpiece works that will help maximize your child's cognitive development. All of these activities are also great at adding excitement to the day, reducing boredom and helping to fend off emotional problems related to anxiety and depression. Natural creative expression should be allowed and facilitated.

\section{Social Issues}

Social issues related to interactions with family and peers are an essential aspect of child development. These include learning emotional regulation skills. Current research thinking says that emotions are important because they are useful to people and serve a function. Some emotions, like fear, help people to avoid danger and injury/ death. Expression of happiness has important social functions. When people show happiness, they tend to bond with another person and make them happy as well. We are born with a set of basic emotions that later become more nuanced and complex due to experience and vocabulary. It is important for children to experience emotions, learn to label them and then to control them. In pandemic parenting, you as a parent will have more opportunities to observe and intervene when needed.

For example, a child who is quick to anger needs to learn what the source is - frustration?, loss?, unfairness? - and how to deal with it appropriately. To simply be angry and act aggressively without a goal (removal or reduction of the cause) is an inappropriate response. Children who do not learn how to properly direct their anger/ aggression can become bullies or otherwise reduce their peer interactions to the point of loneliness.

\section{Pandemic Parenting}

Regulation of emotions refers to both how we display emotions and how we control them. Some of this is related to how your child thinks about their situation. Do you want to look and act very happy in front of your friend if you just won and your friend lost? Do you show anger if another person has provoked you and you do not want them to know they hurt you? So-called display rules are related to knowing when to express emotions appropriately. It is okay to cry and feel sad at a funeral but to not make jokes and laugh loudly. Your child will also learn where it is okay to express emotions. At home, your child will more likely express a fuller range with no censoring. With peers, certain emotions might not be shown to others such as feeling hurt or being embarrassed or humiliated depending on the situation. Equally important is a child's ability to read and understand the emotions of others. This normally happens over the course of the multiple experiences children have interacting with others, from family to friends. One learns that a certain facial expression and tone of voice means a certain emotional type and a probable behavior. For example, when a parent calls a child by first and middle name in a raised voice, the child knows they better be careful with what they next say or do since their parent is upset.

Relationship quality is the final aspect of the social area we will discuss. Within a family, good relations start with the quality of the marital relationship. (In single parent families, that parent 
assumes more responsibility than when it is shared.) It is in a family environment where children first learn about respect and sacrifice and working for the good of all family members. They learn to share and cooperate, to settle differences and make compromises, and to get along with each other. The way this is done is sometimes messy - sibling rivalries, fighting, and grudging acceptance of certain rules and outcomes. This all leads to learning how to live with and work with others. Finally, issues related to anxiety and depression must be considered. As a parent, it is important to observe and pay attention to changes in your child(ren). You may see more moodiness or crying. You may see regressive behaviors such as more dependency or bed-wetting. Increases in fighting or anger can also emerge. In pandemic parenting, a parent needs to respond to such changes by talking with the child. Good conversations can help your child learn to identify and express their feelings. And then you can use your adult experiences to guide your child to the best way to handle their feelings and worries. If your child's behavior becomes significantly worse, you need to consider a consultation with a psychologist or mental health worker. Be careful to intervene before an issue with anxiety or depression goes far beyond your ability to help your child.

\section{Conclusion}

Taking a biopsychosocial approach to adjusting your parenting in this pandemic will allow you to see your child in a holistic way. Looking at each of these three domains will help you to ensure that your child has the least negative outcomes as a result of the pandemic lifestyle we are now forced to operate in. Remember that these areas are interdependent and interactive, so as a parent you need to keep a more global focus as your child develops.

\section{Your next submission with Juniper Publishers will reach you the below assets}

- Quality Editorial service

- Swift Peer Review

- Reprints availability

- E-prints Service

- Manuscript Podcast for convenient understanding

- Global attainment for your research

- Manuscript accessibility in different formats ( Pdf, E-pub, Full Text, Audio)

- Unceasing customer service

Track the below URL for one-step submission https://juniperpublishers.com/online-submission.php 